\title{
Cytogeneticeffectsoftoworganicinsecticidesonmitotic Chromosomes of Alliumsativumroot Tip Cells
}

\author{
Mona S. Al-Ahmadi, \\ Department of Biology, Science College of girls, Dammam University, Dammam, Saudi Arabia
}

\begin{abstract}
In this study, twoorganicinsecticideswere analyzed,namely,Baicao No.2 which is an insecticide extracted from plants and used for Whitefly, Aphid, and Thrips, and Baicaon No.3used for moth. Three different concentrations of both organicinsecticides were examined $(0.25 \mathrm{ml} / \mathrm{l}, 0.5 \mathrm{ml} / \mathrm{l}$, and $1 \mathrm{ml} / \mathrm{liter})$ for different periodsof time (8, 16, and 24 hours) for their cytotoxic and genotoxic effects on cell division (mitotic index) and chromosomes aberration (aberration frequency) on cells of root-tip of Allium sativum .

Low concentration $(0.25 \mathrm{ml} / \mathrm{l})$ ofBaicao No.2 caused an increase inthe mitotic index after ( 8 and 16 hours) of treatment and a decrease after longer time ofexposure (24 hours); it was significantat $p>0.05$.

Higher concentrations of Baicao No.2 $(0.5 \mathrm{ml} / \mathrm{l}$ and $1 \mathrm{ml} / \mathrm{l})$ decreased the mitotic index; it was significantat $p>0.05$.

Treatment with $(0.25 \mathrm{ml} / \mathrm{l})$ ofBaicaon No.3decreased the mitotic index after $(8 \& 16$ hours) and increased the mitotic index after (24 hours); treatment with ( $0.5 \mathrm{ml} / \mathrm{l})$ for (16 and 24 hours) increased the mitotic index; this increase was significant at $p>0.05$, while treatment with $(1 \mathrm{~m} / \mathrm{l})$ decreased the mitotic index after ( 8hours) of exposure and was significant at $p>0.05$, and increased the mitotic index after ( 16 and 24 hours) of exposure; this increase was significantat $p>0.05$.

The tested concentrations of both insecticides causedan increase in aberration frequencyand different types of chromosomal aberration. The chromosomal aberrationwerestickiness anddisturbance chromosomes mostly during metaphase, anaphase stages,andbridges.Low percentage of star- metaphase and lagging chromosomes in telophase cells were observed after treatment with Baicao No.3,also arrest metaphasewere observed in low percentage after treatment with Baicao No.2. The resultsindicatecytotoxic and genotoxiceffects.
\end{abstract}

\section{Introduction:}

For several years,increased attention has been focused on integrated pest management(IPM) programsandalternative methods of pest control to reduce pesticide use in agricultural system because of food safety issues, groundwater contamination, and increased environmental awareness to produce safeand economic crop ( Kovachet al.1992), and several pressures have accelerated research for more environmentally and toxicologically safe and more selective and efficacious pesticides.

Plants contain a virtually untapped reservoir of pesticides that can be used directly as templates for synthetic pesticides. Numerous factors increased the interest of the pesticide industry and pesticide markets in this source of natural products as pesticides, especially, the diminishing return with traditional pesticide use, the number of options in discovery and development of a natural product as a pesticides is larger than synthetic pesticides. Furthermore, limitedmolecular complexity, environmental stability, and low activity of many biocides from plants,compared to synthetic pesticides, are encouraging.

Tens of thousands of secondary products of plants have been identified and there are estimates that hundreds of thousands of these compounds exist.There is growing evidence that most of these compounds are involved in the interaction of plants with other species-primarily the defense of the plant from plant pests (Duke,1990).Eventhough, several researchers found that the aqueous of extracts of some plants inhibited seed germination and seedling growth of wheat and peas. Mitodepressive and radiomimetic effect (Pandya,1975,Shehab,1979,Shehabet al,1978, Mondal, 2006), ( Alametal,1987) observed that the leaf extracts effected the mitotic frequency and caused some abnormal chromosomes.

\section{Materials and Methods}

\section{1-TestedMaterials}

Baicao No.2 is an insecticide extracted from plants; the effective material is $1 \%$ matrine and used forWhitefly, Aphid and Thrips. Baicaon No.3 is a new type of insecticide consists of $0.45 \%$ matrine plus microorganism slight emulsion used for moth. Three different concentrations of both natural pesticide were examined $(0.25 \mathrm{ml} / 1,0.5 \mathrm{ml} / 1$ and $1 \mathrm{ml} /$ liter)for different periods of time $(8,16,24$ hours)for their cytogenetic effect oncell division (mitotic index) and aberration frequency(chromosomes aberration)on cells of root tip of Allium sativum. 


\section{2-SamplePrepartions}

Plant test system is widelyused for monitoring genotoxcity of chemicals because of many advantages such as low cost,easily avaliblity throughout the year,ease of handling, good chromosome condition for the study of chromosome damage and good correlation with other test systems (Sobita and Bhagirath, 2005). In this study,Allium sativem (garlic) $2 \mathrm{~N}=160$ btained from local markets were used as testing material for this study. The loose outer scales and old roots of the garlic were scraped and suspended in small beaker with distilled water.

\section{Treatements}

3.1-Allium sativum were suspended in a small beaker $(50 \mathrm{ml})$ with distilled water to enhance the root tips to grow until they reach $0.5-1 \mathrm{~cm}$ in length; then transfeared to another beakercontaining freshely prepared solution of insecticides and left for different periods of time. Three different concentraions for three different periods of time were used,and one bulbs of garlic was used for each treatment.

3.2-Negative control for each timewas used; the root tips of garlic were treated with distilled water only,and used as a comparative sample for the effects of tested pesticides.

\section{IV. slides preparetion}

The roots were treated with different concentraions $(0.25 \mathrm{ml} / 1,0.5 \mathrm{ml} / 1$, and $1 \mathrm{ml} /$ liter $)$ for periods of time $(8,16,24$ hours),then the roots were detached, fixed in freshly prepared 3:1 (v/v) ethanol alcohol: glacial acetic acid for 24 hours; root tips of Allium sativum were hydrolyzed in 1N HCL at 60 degrees centigrade for 8 minutes; roots tips were then washed with distilled water several times and staind with $1 \%$ acetocarmin, five temporary slides were prepared using the squash technique, two root tips on each slide were examined for the effects ofBaicao No.2 and Baicao No.3 on mitotic index (MI). The same slides were analysed for the types and frequencies of chromosomal abnormalities produced by the examinedpesticides.

\section{Scoring of slides and data analysis}

5.1-The slides were viewed under light microscope (Phenix P H 50 DB047VU) using the 40X objective lens immersion. The most representative ones for each structural aberration were photographed using (Phenix micro Image analyzer Software 2008 En V2, 2)

5.2-Mitotic index: On one slide for each treatment, a total of 2000 cells, were scored. The mitotic index (MI) was expressed as the number of dividing cells per total cells scored.

5.3-Cytotoxicity: The mitotic index of the treated cells at each dose of each insecticide were compared with that of the negative control group

5.4-Genotoxicity test: Chromosomal aberration per dose of each insecticide were examined; the percentage of cells with aberrations of each dose for each insecticide were compared with that of the negative control using the (SPSS 16.0 for Windows statistical package). Two-way Analysis of Variance was the statistical method used for determining the significance of difference at $\mathrm{P}=0.05$.

Mitotic index (MI)

\section{Result and Discussion:}

Three different concentrationsoftwoorganic insecticide $(0.25,0.5 \mathrm{and} 1 \mathrm{ml} /$ liter $)$ were tested for three periods of time $(8,16$, and 24 hours)for theircytotoxic and on mitotic indexand chromosomal aberration comparing with negative control.

Tabel-1 and figures (1\&2) show the effect of Baicao No.2 and Baicao No.3 on the mitotic index (percentage of divided cells)

Baicao No.2: the treatment with $0.25 \mathrm{ml} / 1$ of Baicao No.2caused increasing the mitotic index after 8 and 16 hours of exposure and wassignificant at $\mathrm{p}>0.05$,anddecreased after 24 hours. Both treatments with $0.5 \mathrm{ml} / 1$ and the highest concentration $1 \mathrm{ml} / 1$ of Baicao No.2 caused decreasing the mitotic index after treatment with the three different time periods, especially after 16hours of exposure $(6.85,5.97)$ respectively, compared with negative control(11.45), and was significant at $\mathrm{p}>0.05$.

Baicaon No.3 The mitotic index decreased after treatment with $0.25 \mathrm{ml} / 1$ for 8 and 16 hours, it was significant at $\mathrm{p}>0.05$; while treatment for 24 hours caused increasing in mitotic index; this increase was significant at $\mathrm{p}>0.05$; treatment with $0.5 \mathrm{ml} / \mathrm{l}$ decreased the mitotic index after 8hours of exposure it was significant at $\mathrm{p}>0.05$, and increased the mitotic index after 16 and 24 hours of exposure, it was significantat $\mathrm{p}$ 
$>0.05$; also the highest concentration $1 \mathrm{ml} / 1$ causedsimilar result,treatment for 8hoursand 24 hours causeda decrease in the mitotic index and an increase in the mitotic index after 16 hours; it was significant at $\mathrm{p}>0.05$. The increase of mitotic index can be due to the allelochemical which can act by a innumerous manner to affect the plant germination and growth; the principal mechanisms involves alteration of the mitotic index and suppression of hormones (Rice,1984)(Sousa et al,2009); (Sopovaet al,1983) found that low concentration of tobacco leaf extract exerted stimulating effect, whereas high concentration acted as a mitodepressanton root-tip cells of Allium cepaL.Also (Krivokaoicet al,1970) reported that the weak concentration of immature of SolanumnigrumL. fruits extract stimulate cell division, and that may be due to the presence of a cytokinin-like substance in the extract, whereas stronger concentration reduced the intensity of mitosis.(Koulet al,2005) reported thatbeside active components additional components present and this may affecting the effect of active components, these known and unknown components might be acting as synergistic for the therapeutic and antagonists for the side effects of the active components as well as the other toxic components in the extract.

Decreasing of mitotic index can be explained by the arrest of the division of the interphasic nucleus, as well as by death of intherfasicsnucleus, hindering the onset of prophase and thus the division of the cells (Sousa $e t$ $a l, 2009)$.(Yadav,1986) reported that disrupt the mitotic cycle occur in three ways(1) by inhibiting the process of cell division,(2)by disturbing the normal functioning of the mitotic spindle, and(3)by producing chromosomal abnormalities. Alsoreduction in the percentage of the cell division indicates that the natural insecticide has antimitotic activity, by affecting some vital function units of cell and the normal functioning of the spindle mechanism. (Mondalet al, 2006) observed the same effect on mitotic index after testing the effect of water extract of Ipomoea Species on Allium cepa root tip.

Type of Chromosomal aberrations

Table-2 and figures $(3 \& 4)$ show the type of chromosomes aberrationsafter treatment withBaicao No.2 and Baicaon No.3 insecticides.

Root tips of Allium sativum fixed without treatment served as control and showed normal cell,though some chromosomal aberrations were encountered; These might have arisen due to the automutagenic substance (Dubinin and Scerbako,1962), similarly (Kaushik,1996) reported the occurrence of chromosomal aberrations in water treatment only.

Baicao No. 2 showed that all of the three tested concentrations cause chromosomal abnormalities.Low concentration $0.25 \mathrm{ml} / \mathrm{l}$ cause chromosome aberration namelystickiness and disturbance at metaphases cells and chromosomes disturbanceand bridges in anaphase cells and it wassignificantat $\mathrm{p}>0.05$. Treatment with $0.5 \mathrm{ml} / 1$ for 8 and 24 hour cause chromosome stickiness and bridges,also cause disturbance after root treated for 8,16 , and 24 hours with insecticide. The highest tested concentration $1 \mathrm{ml} / \mathrm{l}$ cause stickiness after 8 hours of treatment and arrested chromosomes (C-metaphase) after 16hours and chromosomes disturbance after 8,16, and 24hours in metaphase cells,cells with anaphase stage shows chromosomes disturbance and bridges after 8hours and lagging chromosome after treatment for 16 hours.

Baicao No.3Treatment with $0.25 \mathrm{ml} / 1$ for 8 hours causes chromosomal stickiness in metaphase cells. Stickiness, disturbance and bridge in the chromosome of anaphase cells, also the tested concentration cause disturbance, bridge and star anaphase after treatment for 16 and 24 hours,star anaphase in low percentage, in telophasecells the treatment induce lagging chromosome after treatment for three time periods and it was significantat $\mathrm{p}>0.05 .0 .5 \mathrm{ml} / \mathrm{l}$ cause chromosome stickiness and star -metaphase.Inanaphase cells treatment with $0.5 \mathrm{ml} / 1$ induce star-anaphase, bridgesand chromosome disturbance; the effect of this concentration was significant at $\mathrm{p}>0.05$.

The highest tested concentration $1 \mathrm{ml} / \mathrm{l}$ cause chromosomaldisturbanceandchromosomal stickiness, also disturbance of anaphase chromosomes, lagging chromosome,bridge, and lagging chromosome in telophase cells. Similar result was observed by (Sudharsan and Reddy,1971 ) and (Kabarity and Malallah,1980)

the stickiness of chromosome that arise after treatment can be explainedasaresult of thedepolymerization of DNA ( Kaushik,1993),(Yadav and Rathora,1984).(Babichet al,1997) reported that metaphases with stickychromosomes lose their normal appearance and appear to have sticky "surface" which causes chromosome agglomeration, possibly due to the effect on chromatin and chromosome organization, disturbance mostly during metaphase and anaphase stagesdue to the failure of spindle mechanism by the treatment (yadav,1986),lagging chromosomeraise from centromere adhesion causing abnormality of chromosomes movement towards the equatorial (Bader et al,1992). Anaphase bridges usually arise because of chromosomes stickiness and end up inhibiting cell division

( Nwakanma and Okoli,2010) .

(Tülay,2012),(Ishidateet $a l$,1988) reported that an increase in chromosomal aberration may result from interactions of a great variety of chemical agents with DNA. 


\section{Conclusion}

The resultsindicate that Both natural insecticides (extracted from plants) have cytotoxiceffect for their effects on mitotic index resulting in decreasing in cell division especially treatment with Baicao No. 2, and found that time of the treatment play an important role for the effects observed; alsoBaicao No.2 and Baicao No.3 have clastogenetic effect because of the chromosomal aberration that absorbedduring $(\mathrm{M})$ phases, that cause the decreasing in cell division.

Table (1):Total number of examined cells , mitotic index and aberration frequency after treatment with different concentrations of insecticides for different periods of time on cells of root tip of Allium sativum

\begin{tabular}{|c|c|c|c|c|c|c|c|}
\hline pesticide & $\begin{array}{c}\text { Concentration/ } \\
\mathrm{Ml} / \mathrm{L}\end{array}$ & $\begin{array}{c}\text { Treatment/ } \\
\text { hour }\end{array}$ & $\begin{array}{l}\text { No. total } \\
\text { cells }\end{array}$ & $\begin{array}{l}\text { divided } \\
\text { cell }\end{array}$ & $\begin{array}{c}\text { total } \\
\text { number of } \\
\text { abnormal } \\
\text { cell }\end{array}$ & $\begin{array}{l}\text { mitotic } \\
\text { index }\end{array}$ & $\begin{array}{l}\text { Aberration } \\
\text { frequency }\end{array}$ \\
\hline \multirow{3}{*}{$\begin{array}{l}\overline{0} \\
\stackrel{0}{0} \\
0\end{array}$} & 0 & 8 & 2052 & 283 & 4 & 13.79 & 0.014 \\
\hline & 0 & 16 & 2436 & 279 & 4 & 11.45 & 0.014 \\
\hline & 0 & 24 & 2069 & 238 & 4 & 11.5 & 0.0168 \\
\hline \multirow{9}{*}{ 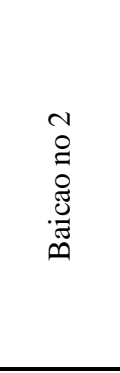 } & 0.25 & 8 & 2523 & 373 & 22 & 14.78 & 0.085 \\
\hline & 0.25 & 16 & 2271 & 299 & 8 & 13.166 & 0.0267 \\
\hline & 0.25 & 24 & 2368 & 225 & 8 & 9.5 & 0.035 \\
\hline & 0.5 & 8 & 2271 & 274 & 7 & 12.065 & "0.0255 \\
\hline & 0.5 & 16 & 2158 & 148 & 7 & 6.85 & 0.047 \\
\hline & 0.5 & 24 & 2053 & 236 & 6 & 11.49 & 0.025 \\
\hline & 1 & 8 & 2157 & 198 & 7 & 9.179 & 0.035 \\
\hline & 1 & 16 & 2579 & 154 & 5 & 5.97 & 0.0029 \\
\hline & 1 & 24 & 2000 & 210 & 4 & 10.5 & 0.019 \\
\hline \multirow{9}{*}{ 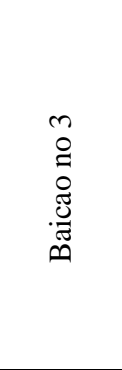 } & 0.25 & 8 & 2659 & 351 & 19 & 13.2 & 0.054 \\
\hline & 0.25 & 16 & 2122 & 203 & 5 & 9.56 & 0.0246 \\
\hline & 0.25 & 24 & 2120 & 268 & 6 & 12.64 & 0.022 \\
\hline & 0.5 & 8 & 2425 & 261 & 7 & 10.76 & 0.0269 \\
\hline & 0.5 & 16 & 2592 & 339 & 13 & 13.07 & 0.038 \\
\hline & 0.5 & 24 & 2147 & 260 & 6 & 12.11 & 0.023 \\
\hline & 1 & 8 & 2269 & 296 & 6 & 13.045 & 0.02 \\
\hline & 1 & 16 & 2133 & 276 & 11 & 12.9 & 0.039 \\
\hline & 1 & 24 & 2187 & 249 & 10 & 11.39 & 0.04 \\
\hline
\end{tabular}

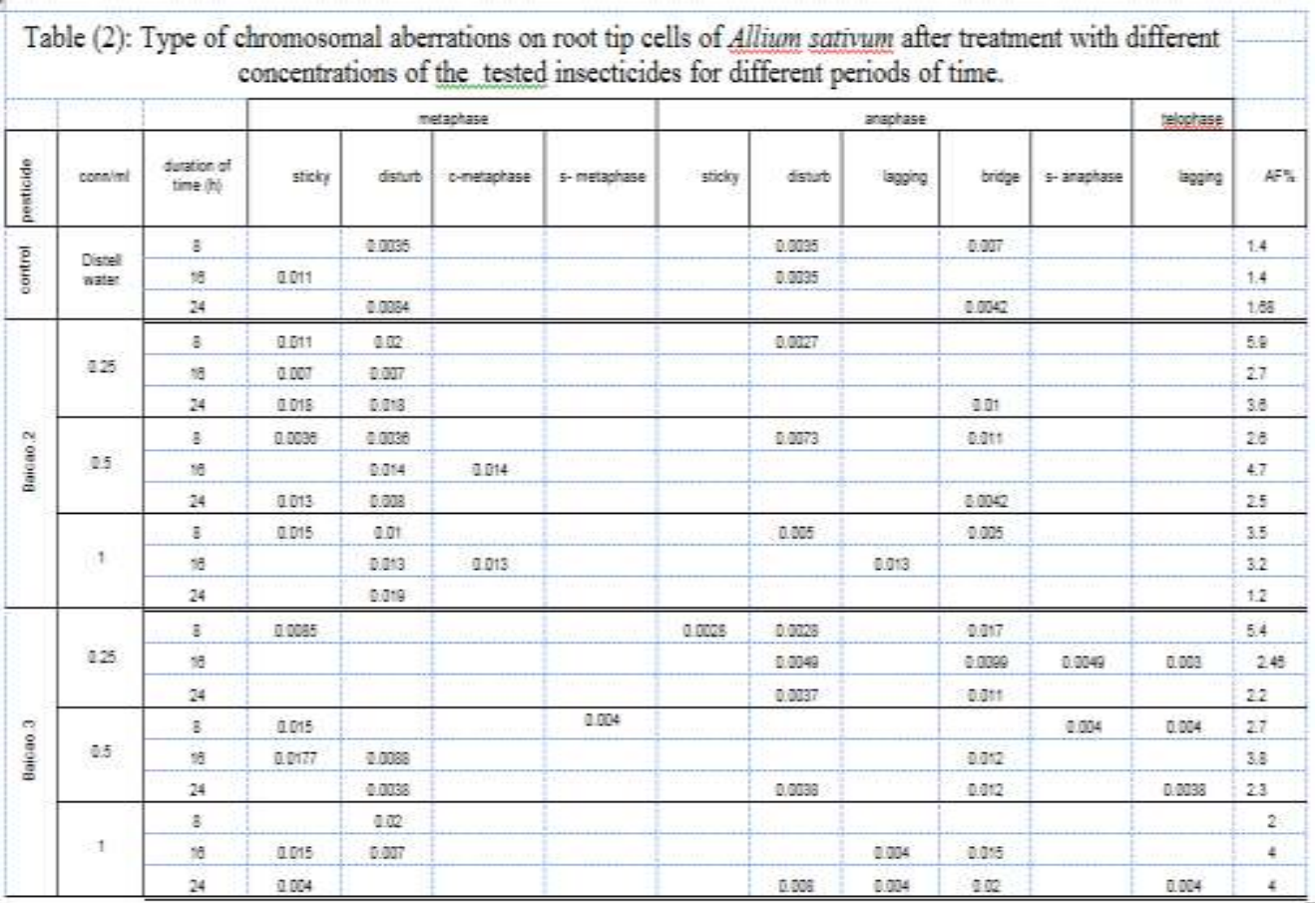

Figures :1- Star metaphase .2- Star anaphase. 3- disturb metaphase .4- C- metaphase. 5- disturbed anaphase. 6\&7- Lagging chromosome at anaphase .8\&9- Bridge at anaphase.. 

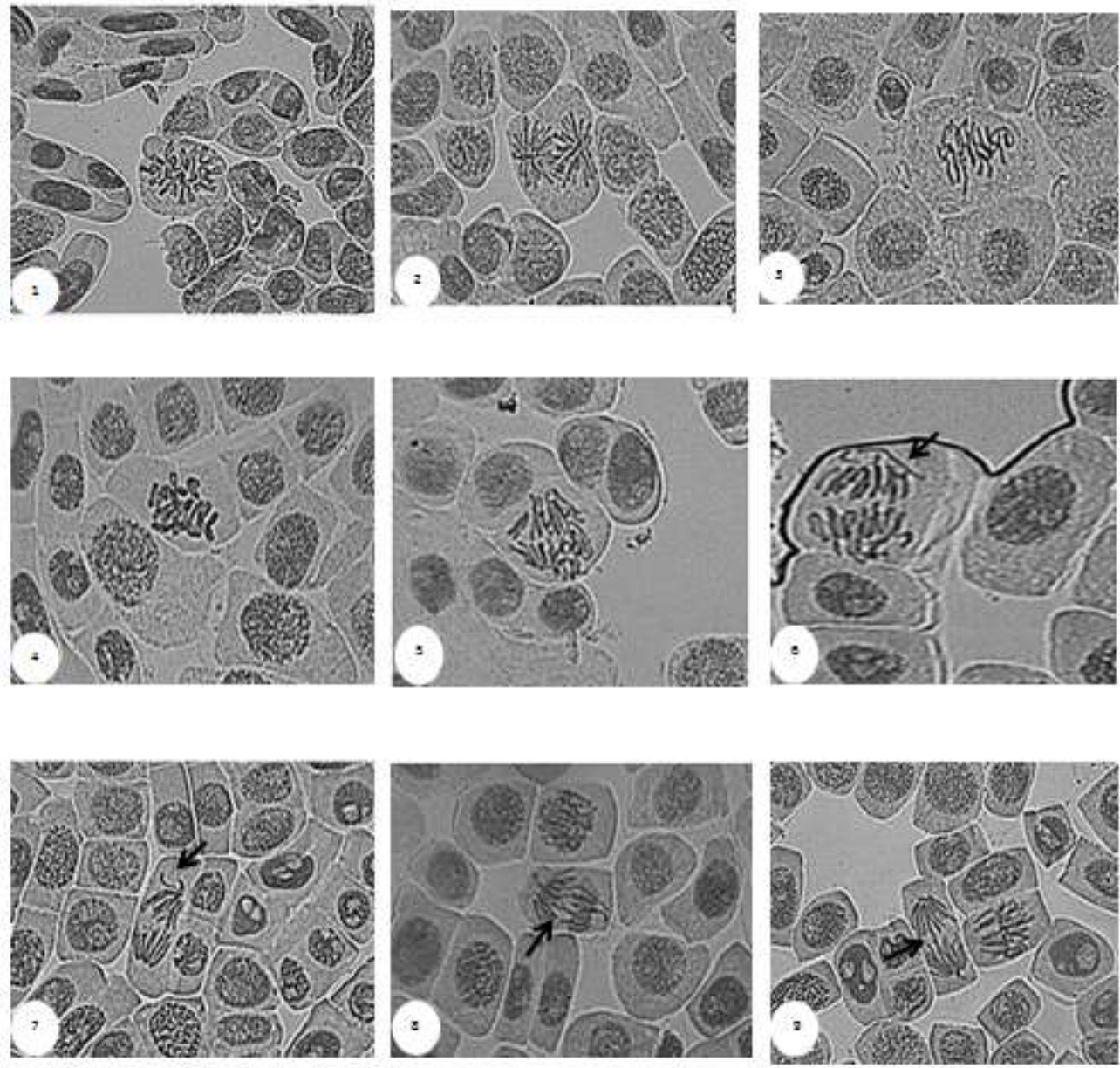

Figur 1: Effect of different concentrations of Paicas no 2 on mitotic index on root tip cells of Allium sativim

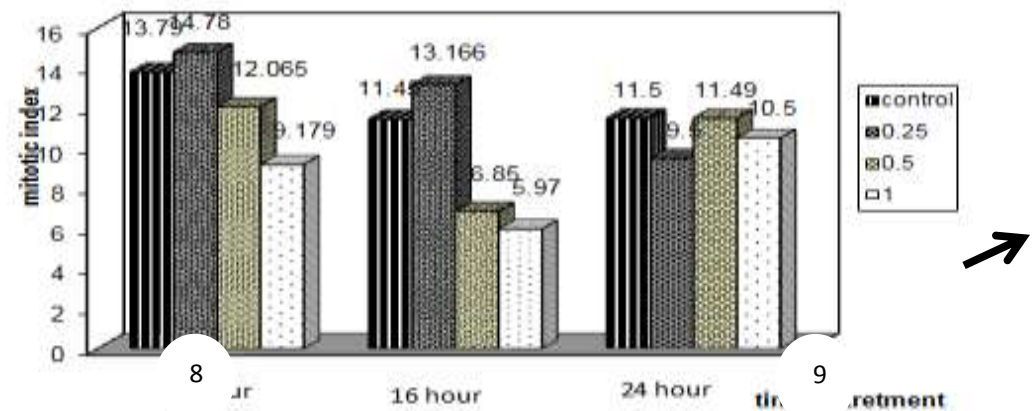

Figur 2: Effect of different concentrations of baic ao no 3 on mitotic

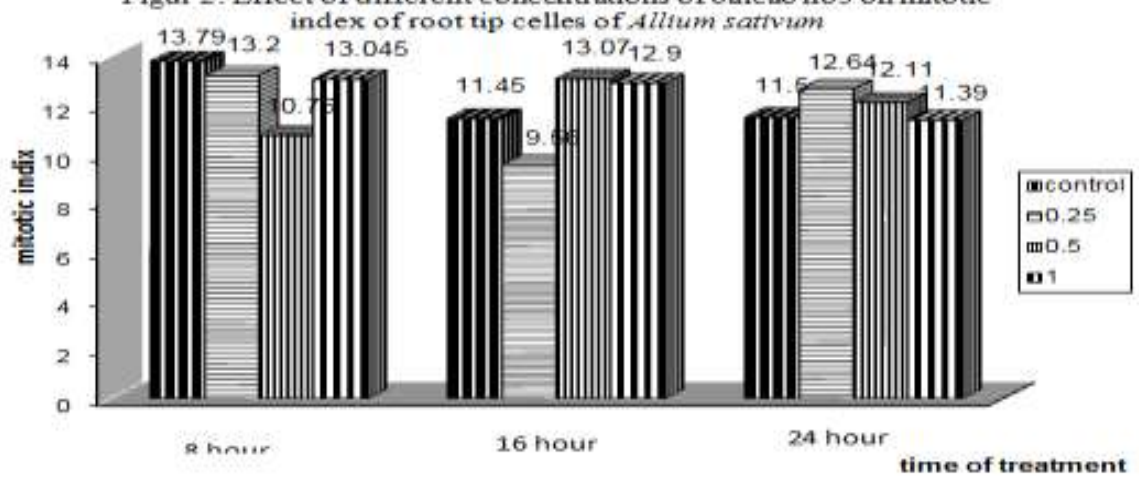




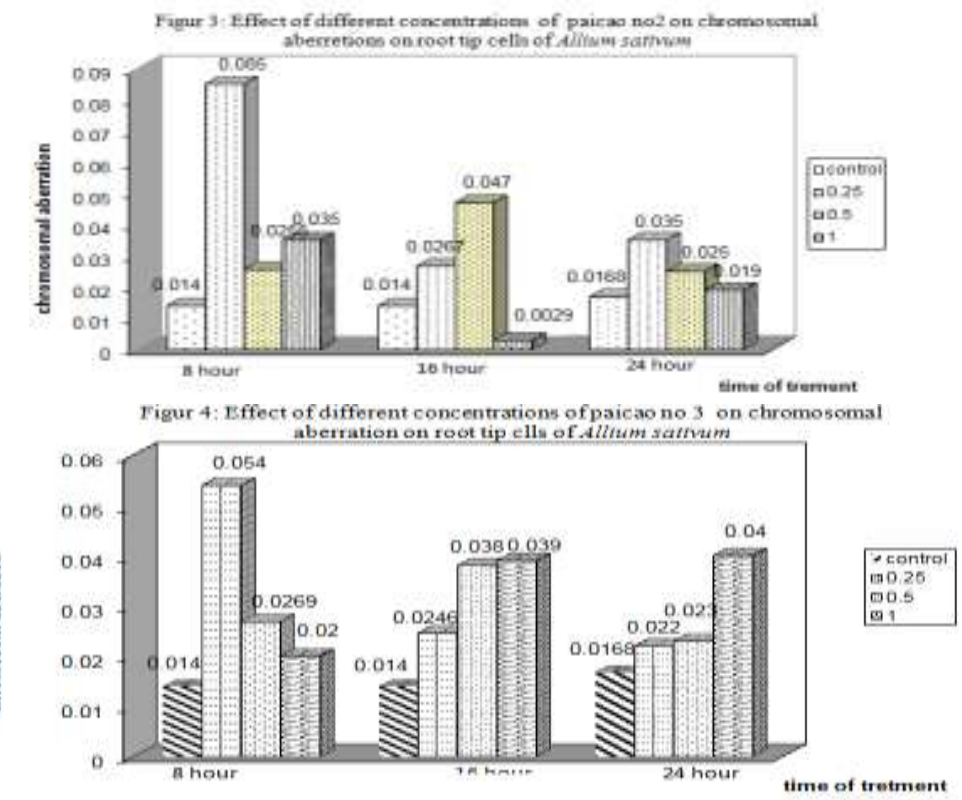

References

[1] Alam,S.,G.Kabir,M.N. Amin and M.Islam.1987.Mitotic effect of leaf extract of Ipomoea carnea on Allium cepa. Cytologia, 52:721-724.

[2] Babich,H.,M.A.Segall,K.D.Fox.1997.The Allium test-Asimple, eukaryote genotoxicity assay .Am Biol Teach., 59:580-583

[3] Badr,A., A. Ghareeb and H.M.El-Din.1992.Cytotoxicity of some pesticides in mitotic cells of Viciafaba roots,Egypt.J.Appl.Sci.7:457-468.

[4] Dubinin,N. P. and V.K.Scerbako.1962.Control of the natural mutation process by means of cysteamine and streptomycin.Proc.Acad.Sci.USSR,145:427-429.

[5] Duk ,S.O.1990 :Natural pesticides from plants. Advances in new crops.Timber Press,Portland,OR.P:511-517.

[6] Kabarity,A.,G.Malallah.1980.Mito-depressive effect of kont extracts in the meristematic region of Allium cepa root tips.Cytologia. 45(4):730-733.

[7] Kaushik,G.C.1996.Cytologcal effects of Lantana cameral L. leaf extract on Viciafaba root tip cells.AD.Plant Sci.9(2):159-164.

[8] Koul,A., S.C.Gangar, and V.Sandhir .2005.Pitfalls in journey from traditional to modern medicine.Natural Product Radiance Sin.,24:7-21.

[9] Kovach,J.,C.Petzoldt,J.Degnil, and J.Tette,1992. Amethod To Measure TheEnvironmental Impact of Pesticides. IPM Program Cornell University.New York State Agricultural Experiment Station Geneva, NewYork 14456 (Cornell Cooperative Extension,Lewis County, Lowville,NewYork13367.

[10] Krivokapic,K.,R.Hadziselimovic, A.Sofradzija.1970.Effect of extract from immature fruits of Solanumnigrum on the intensity of mitosis in Allium sativum.Iugosl.Physiol.Pharmacol.Acta, 6:363-367.

[11] Mondal, A., G.Kabir,N.Yasmin ,A.M.S. Alam and H.A.Khatun,2006.Mitotic effect of water extract of different Ipmoea Species on Allium cepa L. Pakistan journal of Biological Sciences, 9:1116-1120.

[12] Nwakanma,N.M.C.,B.E.Okoli.2010.Cytological effects of the root extracts of Boehaaviadiffusa on root tips of Crinum jagus.EurAsia J BioSci4:105-111.

[13] Pandya,S.M., 1975.Effect of Celosia argentea extracts on root and shoot growth of bajraseedilng. Geobios,2: 175-178.

[14] Rice,E.L.,1984.Allelopathy. $2^{\text {nd }}$ ED. NewYork: Academic Publichers 424pp.

[15] Sazada,S.,S.Alamari,M.K.Meghvanst,S.S.Khan,2010.Evaluting the toxic effects of FicusinfectoriaRoxb and EmblicaofficianlisGaertn. Leaf extracts on cell division and chromosomal morphology of Cicerarietinum L.2010. Journal of Ecobiotechnology 2(1):49-52.

[16] Sharma, A. K. and A.Gupta.1959.Chromosome breakage with plant pigment.Nature.184:1821.

[17] Sharma, A. K. and B.Dutta.1962.Radiomimetic effects of plant pigments. Folia Biologica,10:59-65. tipserh

[18] Shehab, A.S., 1979. Cytological effects of Medicinal plants in Qutar I mitotic effect of water extract of PulicariacrspaandAlliumcepa. Cytologia 44:607-613.

[19] Shehab, A.S., H.A.Hakeem and A.E. Kheir, 1978. Cytological effects of Achilleafragrantissima extract on Allium cepa and Viciafaba. Cytologia 43:623-629.

[20] Sobita,A. and T.H.Bhagirath,2005. Effect of some medicinal plant extracts on Viciafaba root tip chromosomes.Cytologia,58(3):255-261.

[21] Sobita,K.and Bhagirath,T.2005. Effect of some medicinal plants extracts on Viciafaba root tip chromosomes. Caryologia 58:255261.

[22] Sopova,M.,Z.Sekovski, and M. Jovanovska.1983.Cytological effect of tobacco leaf extract on root tip cells of Allium sativum .Acta Biol.Med.Exp.,8:49-56.

[23] Sousa,S.M.,S.S.Pamela.,M.S.Jose',L.F.Camos and F.V.Lyderson.2009.Cytotoxic and genotoxic effects of two medicinal species of Verbenaceae.Cytologia,62(4):326-333.

[24] Tülay, A.C.2012.Potential Genotoxic and cytotoxicects of Plant extracts ,Compendium of assays on Alternative Therapy ,Dr .Arup Bhattacharya (Ed.),ISBN:978-953-307-863-2.In Tech.

[25] Yadav,S.K.1986.Antimitotic and cytological activities of tropical forest tree: Tamarindusindica.Journal of tropical Forestry.2(1):53-58.

[26] Yadav,S.K. and J.S.Rathore.1984.Cytological effectsof the equeous fruit extracts of Emblicaofficinalss on Allium sativum root tips.Egypt.J..Cenet.Cylot.13:181-185. 